\title{
Mahella australiensis gen. nov., sp. nov., a moderately thermophilic anaerobic bacterium isolated from an Australian oil well
}

Correspondence

Bernard Ollivier

ollivier@esil.univ-mrs.fr

\author{
Monica Bonilla Salinas, ${ }^{1}$ Marie-Laure Fardeau, ${ }^{1}$ Pierre Thomas, ${ }^{1}$ \\ Jean-Luc Cayol, ${ }^{1}$ Bharat K. C. Patel ${ }^{2}$ and Bernard Ollivier ${ }^{1}$ \\ ${ }^{1}$ IRD, UR 101 Extrêmophiles, IFR-BAIM, Universités de Provence et de la Méditerranée, ESIL, \\ Marseille, France \\ ${ }^{2}$ School of Biomolecular and Biomedical Sciences, Griffith University, Brisbane, Australia
}

\begin{abstract}
A novel Gram-positive, anaerobic and moderately thermophilic bacterium, strain $50-1 \mathrm{BON}^{\top}$, was isolated from an Australian terrestrial oil reservoir. Cells were spore-forming straight rods, motile by peritrichous flagella. The optimum growth conditions were $50^{\circ} \mathrm{C}, \mathrm{pH} 7.5$ and $0.1 \%$ $\mathrm{NaCl}$. Strain 50-1 BON ${ }^{\top}$ fermented arabinose, cellobiose, fructose, galactose, glucose, mannose, sucrose, xylose and yeast extract. Glucose was fermented mainly into lactate, formate, hydrogen and $\mathrm{CO}_{2}$. The major end product of pyruvate fermentation was acetate together with $\mathrm{H}_{2}$ and $\mathrm{CO}_{2}$. Thiosulfate, sulfate, elemental sulfur and nitrate were not used as terminal electron acceptors. The DNA G $+\mathrm{C}$ content was $55.5 \mathrm{~mol} \%$. The closest phylogenetic relative of strain 50-1 BON ${ }^{\top}$ was Thermoanaerobacterium thermosulfurigenes (16S rRNA gene sequence similarity of $85 \cdot 7 \%$ ). As strain $50-1 \mathrm{BON}^{\top}$ was physiologically and phylogenetically different from members of the order 'Thermoanaerobacteriales', it is proposed that strain $50-1 \mathrm{BON}^{\top}$ (=DSM $15567^{\top}=$ CIP $107919^{\top}$ ) be classified as the type strain of a novel species of a new genus, Mahella australiensis gen. nov., sp. nov.
\end{abstract}

Mesophilic, thermophilic and hyperthermophilic fermentative bacteria constitute an important microbial community of the oilfield environment (Magot et al., 2000). Cloning and sequencing of PCR-amplified 16S rRNA genes of oilfield microbial communities have suggested the presence of a limited number of anaerobes belonging to the class 'Clostridia', e.g. Clostridium spp. and Eubacterium spp. (Voordouw et al., 1996). However, there is increasing evidence that mesophilic and thermophilic members of the Clostridiales are current inhabitants of oilfield ecosystems. They include: (i) sulfate-reducing bacteria of the genus Desulfotomaculum, family Peptococcaceae (Nazina et al., 1988; Nilsen et al., 1996), (ii) thermophilic fermentative micro-organisms of the genera Thermoanaerobacter and Thermoanaerobacterium, family 'Thermoanaerobacteriaceae' (Cayol et al., 1995; Grassia et al., 1996), and (iii) a mesophilic fermentative bacterium of the genus Fusibacter, family Clostridiaceae (Ravot et al., 1999). We have recently performed investigations on the microbiology of anaerobes inhabiting oil reservoirs in Queensland, Australia. Here we describe a novel thermophilic anaerobic bacterium (strain 50-1 $\mathrm{BON}^{\mathrm{T}}$ ) isolated from a non-water-flooded terrestrial oil reservoir, which belongs to cluster VI of the order

The GenBank/EMBL/DDBJ accession number for the 16S rRNA gene sequence of strain $50-1 \mathrm{BON}^{\top}$ is $\mathrm{AY} 331143$.
Clostridiales. Strain 50-1 BON ${ }^{\mathrm{T}}$ presented significant phenotypic and genotypic differences, and we propose that it be classified in a new genus and species, Mahella australiensis gen. nov., sp. nov.

The oil sample used in this study was collected from the Riverslea oilfield in the Bowen-Surat Basin of Queensland in eastern Australia. The sample has been designated OCA5 and was stored at $4{ }^{\circ} \mathrm{C}$ until used.

Enrichment was performed in a medium prepared anaerobically (Fardeau et al., 2000) containing $\left(1^{-1}\right.$ distilled water): $0.3 \mathrm{~g} \mathrm{~K}_{2} \mathrm{HPO}_{4}, 0.3 \mathrm{~g} \mathrm{KH}_{2} \mathrm{PO}_{4}, 0.2 \mathrm{~g} \mathrm{MgCl}_{2} .6 \mathrm{H}_{2} \mathrm{O}, 0.1 \mathrm{~g}$ $\mathrm{CaCl}_{2} \cdot 2 \mathrm{H}_{2} \mathrm{O}, 0.5 \mathrm{~g}$ cysteine hydrochloride, $1 \mathrm{mg}$ resazurin, $0 \cdot 1 \mathrm{~g} \mathrm{KCl}, 1 \mathrm{~g} \mathrm{NaCl}, 1 \mathrm{~g} \mathrm{NH}_{4} \mathrm{Cl}, 5 \mathrm{~g}$ yeast extract, $5 \mathrm{~g}$ bioTrypticase (Difco) and $10 \mathrm{ml}$ of the trace mineral solution of Balch et al. (1979). The pH was adjusted to $7 \cdot 0$ with $10 \mathrm{M}$ $\mathrm{KOH}$. Vessels were autoclaved for $45 \mathrm{~min}$ at $110^{\circ} \mathrm{C}$. Prior to inoculation, $\mathrm{Na}_{2} \mathrm{~S} .9 \mathrm{H}_{2} \mathrm{O}$ and $\mathrm{NaHCO}_{3}$ were added from sterile stock solutions. For enrichment, a $2 \mathrm{ml}$ oil well water sample was inoculated into $20 \mathrm{ml}$ medium and incubated at $50{ }^{\circ} \mathrm{C}$. Three enrichment series were performed in the same medium before isolation. Strains were isolated by repeated use of the Hungate roll-tube technique (Hungate, 1969), with medium solidified with $2 \%$ noble agar (Difco). The process of serial dilution in roll tubes was repeated at least twice to purify the cultures. 
The basal medium used for characterization of $\mathrm{pH}$, temperature and $\mathrm{NaCl}$ ranges for growth of the isolates was similar to the enrichment medium supplemented with $20 \mathrm{mM}$ glucose. The culture medium was adjusted to different $\mathrm{pH}$ values by injecting $\mathrm{NaHCO}_{3}$ from $10 \%(\mathrm{w} / \mathrm{v})$ sterile anaerobic stock solutions. Water baths were used to obtain incubation temperatures up to $100^{\circ} \mathrm{C}$. For studies of $\mathrm{NaCl}$ requirements, $\mathrm{NaCl}$ was weighed directly in the tubes prior to dispensing the medium. The characterized strain was subcultured at least once under the same experimental conditions prior to determination of growth rates. Substrates were tested in anaerobiosis in basal medium at a final concentration of $20 \mathrm{mM}$. To test for electron acceptors, sodium thiosulfate $(20 \mathrm{mM})$, sodium sulfate $(20 \mathrm{mM})$, sodium sulfite $(2 \mathrm{mM})$, elemental sulfur $(2 \%, \mathrm{w} / \mathrm{v})$, potassium nitrate $(10 \mathrm{mM})$ and potassium nitrite $(2 \mathrm{mM})$ were added to the medium. The use of electron acceptors was evaluated by measuring $\mathrm{OD}_{580}$ and sulfide, ammonium or nitrite production. The presence of spores was tested by phase-contrast microscopic observations of young and old cultures and after pasteurization tests performed at 80, 90 and $100{ }^{\circ} \mathrm{C}$ for 10 and $20 \mathrm{~min}$. Antibiotics were added at $20,25,50,100,150$ and $200 \mu \mathrm{g} \mathrm{ml}^{-1}$ and the resulting growth was compared with a control with no antibiotic added.

Unless otherwise indicated, duplicate culture tubes were used throughout these studies. Growth was determined by measurement of OD at $580 \mathrm{~nm}$ using a UV-visible spectrophotometer 50 Scan (Varian). Sulfide was determined photometrically as colloidal CuS by the method of CordRuwisch (1985). Nitrate and nitrite were estimated using the Quantofix test (Macherey-Nagel). Organic compounds were determined as described by Fardeau et al. (1997). Morphological characteristics of isolates were observed with an Optiphot phase microscope (Nikon). The electron microscopy studies were performed as described by Koussémon et al. (2001).

The $\mathrm{G}+\mathrm{C}$ content of DNA was determined at the Deutsche Sammlung von Mikroorganismen und Zellkulturen $\mathrm{GmbH}$ (Braunschweig, Germany) using HPLC as described by Mesbah et al. (1989). Non-methylated $\lambda$ DNA (Sigma) was used as the standard. The 16S rRNA gene of the isolate was amplified as described previously (Miranda-Tello et al., 2003). PCR products were cloned using the pGEM-T Easy cloning kit (Promega), according to the manufacturer's protocol. The clone libraries were screened by direct PCR amplification from a colony using the vector-specific primers SP6 (5'-ATTTAGGTGACACTATAGAA-3') and T7 (5'-TAATACGACTCACTATAGGG-3') and the following reaction conditions: $2 \mathrm{~min}$ at $96^{\circ} \mathrm{C}, 40$ cycles of $30 \mathrm{~s}$ at $94^{\circ} \mathrm{C}, 1 \mathrm{~min}$ at $55^{\circ} \mathrm{C}$ and $3 \mathrm{~min}$ at $72^{\circ} \mathrm{C}$ and a final extension of $10 \mathrm{~min}$ at $72^{\circ} \mathrm{C}$. Plasmids containing an insert of the correct length were isolated using the Wizard Plus SV Minipreps DNA Purification System kit (Promega), according to the manufacturer's protocol. Purified plasmids were sent to Genome Express (Grenoble, France) for sequencing.
Sequence data were aligned with a full-length consensus $16 \mathrm{~S}$ rRNA gene sequence, assembled and checked for accuracy manually using the alignment editor BioEdit v5.0.9 (Hall, 1999). These were compared with other sequences in GenBank (Benson et al., 1999) and RDP (Maidak et al., 2001) using BLAST (Altschul et al., 1997) to identify the closest relatives. Positions of sequence and alignment ambiguity were omitted and pairwise evolutionary distances based on 1373 unambiguous nucleotides were computed using the method of Jukes \& Cantor (1969). A dendrogram was constructed using the neighbour-joining method (Saitou \& Nei, 1987). Confidence in the tree topology was determined by using 100 bootstrapped trees (Felsenstein, 1993). The 16S rRNA gene sequence accession numbers of reference organisms are included in Fig. 2.

Enrichment cultures were positive after incubation at $50{ }^{\circ} \mathrm{C}$ for 3-4 days. Microscopic examination revealed the presence of motile, rod-shaped bacteria. White, round, smooth colonies (1-2 $\mathrm{mm}$ in diameter) developed on roll tubes after 7 days of incubation. Single colonies were picked and streaking was repeated three times before cultures were considered to be pure. Two strains similar in morphology were isolated: strain 50-1 BON ${ }^{\mathrm{T}}$ and strain 50-2 BON. As these strains shared $100 \%$ similarity in their 16S rRNA gene sequences, strain $50-1 \mathrm{BON}^{\mathrm{T}}$ was used for further characterization. Cells of strain $50-1 \mathrm{BON}^{\mathrm{T}}$ were straight rods, 3-20 $\mu \mathrm{m}$ in length and $0 \cdot 5 \mu \mathrm{m}$ in diameter (Fig. 1), motile by peritrichous flagella (mean of four flagella per cell). Terminal spores (mean $1.2 \mu \mathrm{m}$ in diameter) swelling the cells were observed (Fig. 1). Ultra-thin sections of the cells showed a Gram-positive-type cell wall (data not shown). Cells divided by septation of the cell wall. Strain $50-1 \mathrm{BON}^{\mathrm{T}}$ grew at temperatures ranging from 30 to $60^{\circ} \mathrm{C}$, and growth was optimum at $50{ }^{\circ} \mathrm{C}$ (data not shown). Growth occurred at initial pH values between 5.5 and 8.8 at $50^{\circ} \mathrm{C}$, with the optimum at $\mathrm{pH} 7 \cdot 5$ (data not shown). The isolate grew at $\mathrm{NaCl}$ concentrations ranging from 0 to $4 \%$, with the

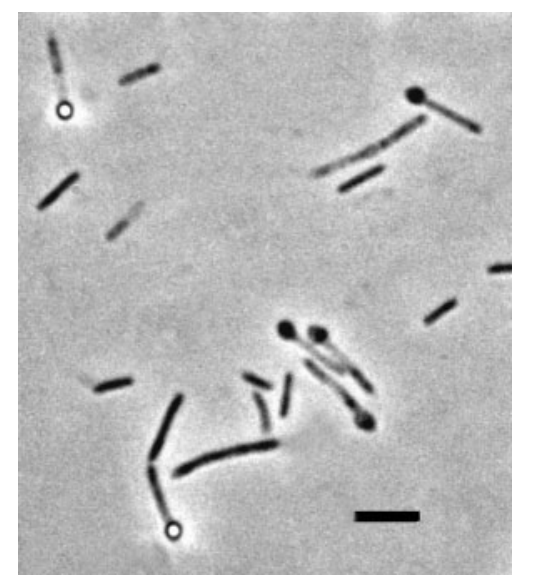

Fig. 1. Phase-contrast micrograph of strain 50-1 $B O N^{\top}$ grown under optimal conditions showing sporulating cells. Bar, $10 \mu \mathrm{m}$. 


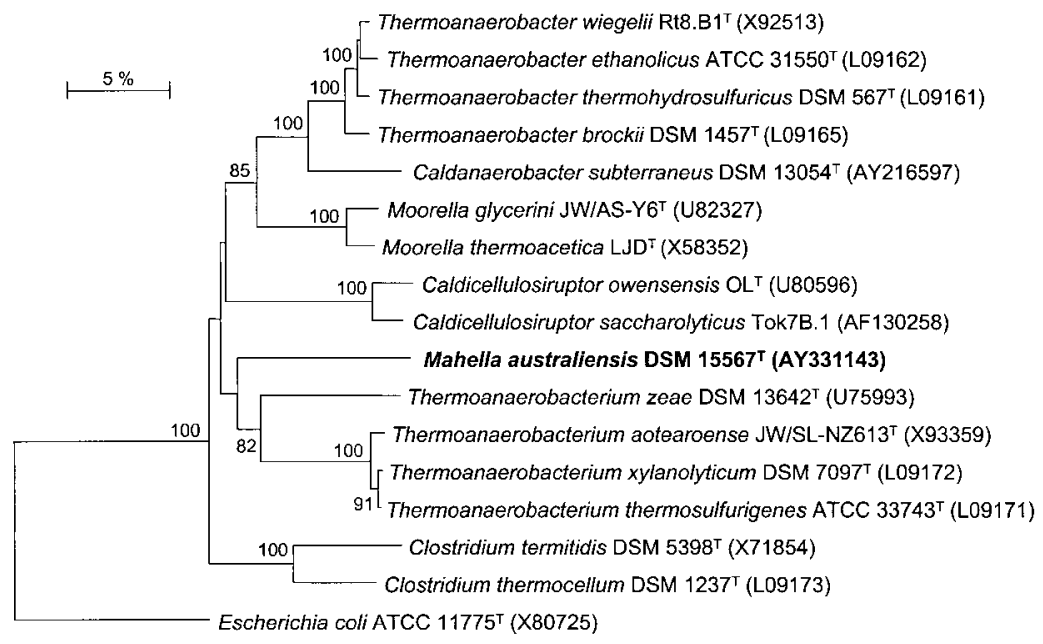

Fig. 2. Dendrogram based on $16 \mathrm{~S}$ rRNA gene sequences generated by the neighbourjoining method (Saitou \& Nei, 1987) indicating the phylogenetic position of strain 50-1 $\mathrm{BON}^{\top}$. GenBank accession numbers are shown. Bootstrap values from 100 replications are shown at branching points. Only values above 80 were considered significant and are reported. Bar, 5 substitutions per 100 nucleotides.

optimum at $0 \cdot 1 \% \mathrm{NaCl}$ (data not shown). The doubling time under optimal conditions was $11 \mathrm{~h}$.

Yeast extract was not required for growth but increased growth. In the presence of yeast extract, the OD was four times higher than in its absence. Strain $50-1 \mathrm{BON}^{\mathrm{T}}$ grew under anaerobiosis with the following substrates as carbon and energy sources: arabinose, cellobiose, fructose, galactose, glucose, mannose, sucrose, xylose and yeast extract. Glucose was degraded mainly into lactate $[1 \cdot 3 \mathrm{~mol}$ (mol glucose consumed $\left.)^{-1}\right]$, formate $[1.5 \mathrm{~mol}$ (mol glucose consumed $\left.)^{-1}\right]$, hydrogen and $\mathrm{CO}_{2}$, together with acetate $\left.[0 \cdot 2 \mathrm{~mol} \text { (mol glucose consumed })^{-1}\right]$ and ethanol $[0.5 \mathrm{~mol}$ (mol glucose consumed $\left.)^{-1}\right]$. Acetate together with $\mathrm{H}_{2}$ and $\mathrm{CO}_{2}$ were the major end products of pyruvate fermentation. The following compounds were not fermented: ethanol, methanol, 1-propanol, glycerol, 1,2-propanediol, olive oil, starch, benzoate, formate, succinate, lactate, fumarate, acetate, propionate, peptone and Casamino acids. Electron acceptors tested were not used.

Penicillin and ampicillin did not inhibit growth at concentrations up to $200 \mu \mathrm{g} \mathrm{ml}^{-1}$, but growth was inhibited by chloramphenicol at a concentration of $50 \mu \mathrm{g} \mathrm{ml}^{-1}$.

The first isolations and partial characterizations of thermophilic fermentative micro-organisms originating from hightemperature petroleum reservoirs were performed in the 1980s (Levi et al., 1985; Shenman \& Vance, 1987). Further studies provided evidence that thermophilic anaerobes are an important microbial community of the oilfield ecosystems (Cayol et al., 1995; Grassia et al., 1996; L'Haridon et al., 1995; Magot et al., 2000; Stetter et al., 1993). Strain 50-1 $\mathrm{BON}^{\mathrm{T}}$ was isolated from a non-water-flooded Australian oilfield in Queensland. It was found to be a moderately thermophilic, spore-forming anaerobe that utilized a wide range of carbohydrates, lactate being a major end product of glucose metabolism. Spores were round, terminal, distending the cells and were brightly refractile under phase-contrast microscopy (Fig. 1). However, similarly to Thermoanaerobacter brockii (formerly Thermoanaerobium brockii), non-refractile structures could be observed in the same position within the cells and were assumed to be prespores (Cook et al., 1991). 16S rRNA gene sequence analysis revealed that strain $50-1 \mathrm{BON}^{\mathrm{T}}$ was a member of cluster VI of the order Clostridiales and its closest phylogenetic relatives were members of the genus Thermoanaerobacterium, family 'Thermoanaerobacteriaceae', class 'Clostridia' (Fig. 2). This family also includes members of the genus Thermoanaerobacter, which, similarly to members of the genus Thermoanaerobacterium, are known to use thiosulfate as a terminal electron acceptor, reducing it to sulfide or elemental sulfur (Lee et al., 1993; Wiegel \& Ljungdahl, 1981). This is the case for Thermoanaerobacterium thermosulfurigenes, isolated from a thermal, volcanic, algalbacterial community (Schink \& Zeikus, 1983), and Thermoanaerobacterium aotearoense, isolated from geothermally heated water and sediments collected in New Zealand (Liu et al., 1996), the closest phylogenetic relatives of strain $50-1 \mathrm{BON}^{\mathrm{T}}$ (similarities of $85 \cdot 7$ and $85 \cdot 5 \%$ with Thermoanaerobacterium thermosulfurigenes and Thermoanaerobacterium aotearoense, respectively). In contrast to Thermoanaerobacterium thermosulfurigenes and Thermoanaerobacterium aotearoense, strain $50-1 \mathrm{BON}^{\mathrm{T}}$ was unable to reduce thiosulfate and did not grow at temperatures above $60^{\circ} \mathrm{C}$. In addition, strain $50-1 \mathrm{BON}^{\mathrm{T}}$ had a different DNA G $+\mathrm{C}$ content $(55 \cdot 5 \mathrm{~mol} \%$ for strain $50-1$ $\mathrm{BON}^{\mathrm{T}}$ compared with $32.6 \mathrm{~mol} \%$ for Thermoanaerobacterium thermosulfurigenes and $34 \cdot 5-35 \mathrm{~mol} \%$ for Thermoanaerobacterium aotearoense). Strain 50-1 BON $\mathrm{BO}^{\mathrm{T}}$ also differed from both Thermoanaerobacterium species by the range of optima and growth conditions, and by the range of substrates used (Table 1). Within the genus Clostridium, strain 50-1 BON ${ }^{\mathrm{T}}$ has Clostridium thermocellum as its closest phylogenetic relative (similarity of $84 \cdot 8 \%$ ). However, the latter uses cellulose and cellulose relatives but not sugars $(\mathrm{Ng}$ et al., 1977). In addition, it grows at temperatures above $60{ }^{\circ} \mathrm{C}$ and has a lower DNA G $+\mathrm{C}$ content $(38 \cdot 1-39 \cdot 5 \mathrm{~mol} \%$ for C. thermocellum). In this respect, strain $50-1 \mathrm{BON}^{\mathrm{T}}$ clearly differed phylogenetically and phenotypically from anaerobic spore-forming bacteria known so far. This strain 
Table 1. Discriminating characteristics between strain $50-1 \mathrm{BON}^{\top}$ and its closest relatives Thermoanaerobacterium thermosulfurogenes and Thermoanaerobacterium aotearoense

Data for reference species were taken from Schink \& Zeikus (1983) (T. thermosulfurogenes) and Liu et al. (1996) (T. aotearoense). ND, Not determined.

\begin{tabular}{|c|c|c|c|}
\hline Characteristic & Strain $50-1 \mathrm{BON}^{\mathrm{T}}$ & T. thermosulfurogenes & T. aotearoense \\
\hline Temperature range $\left({ }^{\circ} \mathrm{C}\right)$ & $30-60$ & $35-75$ & $35-66$ \\
\hline Optimum temperature $\left({ }^{\circ} \mathrm{C}\right)$ & 50 & 60 & $60-63$ \\
\hline $\mathrm{pH}$ range & $5 \cdot 5-8 \cdot 8$ & $4 \cdot 0-7 \cdot 6$ & $3 \cdot 8-6 \cdot 8$ \\
\hline Optimum pH & $7 \cdot 5$ & $5 \cdot 5-6 \cdot 5$ & $5 \cdot 2$ \\
\hline DNA G $+C$ content $(\mathrm{mol} \%)$ & $55 \cdot 5$ & $32 \cdot 6$ & $34 \cdot 5-35 \cdot 0$ \\
\hline Reduction of thiosulfate & - & + & + \\
\hline \multicolumn{4}{|l|}{ Substrates used: } \\
\hline Arabinose & + & + & - \\
\hline Starch & - & + & + \\
\hline Pyruvate & + & - & - \\
\hline Doubling time on glucose $(\mathrm{h})$ & $11 \cdot 0$ & $1 \cdot 9$ & ND \\
\hline End products of glucose metabolism & $\begin{array}{l}\text { Lactate, formate, } \\
\text { ethanol, acetate, } \mathrm{H}_{2}, \mathrm{CO}_{2}\end{array}$ & $\begin{array}{l}\text { Ethanol, acetate, } \\
\text { lactate, } \mathrm{H}_{2}, \mathrm{CO}_{2}\end{array}$ & $\begin{array}{l}\text { Ethanol, acetate, } \\
\text { lactate, } \mathrm{H}_{2}, \mathrm{CO}_{2}\end{array}$ \\
\hline
\end{tabular}

was isolated from a non-water-flooded reservoir, which is the best model for studying indigenous bacteria. Whether this strain is of indigenous or exogenous origin is difficult to conclude, since contamination could occur in a number of ways during working of the oilfields (e.g. drilling, well equipment operations and damaged tubing). However, the hypothesis that micro-organisms might be indigenous to petroleum reservoirs has been presented by several authors (Grassia et al., 1996; L'Haridon et al., 1995; Ollivier et al., 1998) and deserves further consideration. Indeed, the improvement of our knowledge of the metabolic diversity of oil reservoir microbial inhabitants will be helpful in developing microbial processes to enhance oil recovery.

Because of its phenotypic, genotypic and phylogenetic characteristics, strain $50-1 \mathrm{BON}^{\mathrm{T}}$ represents a novel species of a new genus within the family Thermoanaerobacteriaceae that we propose to name Mahella australiensis gen. nov., sp. nov.

\section{Description of Mahella gen. nov.}

Mahella (Mah.el'la. L. dim. ending -ella; N.L. fem. n. Mahella named in honour of the American microbiologist Professor R. A. Mah, for his important contribution to the taxonomy of anaerobes).

Cells are straight rods. Gram reaction is positive. Spores are formed. Growth is anaerobic. Moderately thermophilic member of class 'Clostridia', family 'Thermoanaerobacteriaceae'. Sugars serve as main substrates with lactate and formate being major end products of sugar metabolism. The type species is Mahella australiensis.

\section{Description of Mahella australiensis sp. nov.}

Mahella australiensis (aus.tra.li.en'sis. N.L. fem. adj. australiensis related to Australia).
Displays the following properties in addition to those given in the genus description. Cells $(3-20 \times 0.5 \mu \mathrm{m})$ occur singly or in pairs and possess peritrichous flagella. Electron microscopy shows a Gram-positive-type cell wall. Round colonies (1-2 mm diameter) develop in roll tubes after 7 days of incubation at $50{ }^{\circ} \mathrm{C}$. Chemo-organotrophic and obligately anaerobic. Ferments arabinose, cellobiose, fructose, galactose, glucose, sucrose, $\mathrm{D}$-xylose and pyruvate. The optimum temperature for growth is $50{ }^{\circ} \mathrm{C}$ at $\mathrm{pH} \mathrm{7.5}$; temperature range between 30 and $60{ }^{\circ} \mathrm{C}$. The optimum $\mathrm{pH}$ is $7 \cdot 5$; growth occurs between $\mathrm{pH} 5 \cdot 5$ and $8 \cdot 8$. Halotolerant, growing in the presence of up to $4 \% \mathrm{NaCl}$ with an optimum at $0 \cdot 1 \%$. Yeast extract is not required for growth. Elemental sulfur, sulfate, thiosulfate, sulfite, nitrate or nitrite is not used as an electron acceptor. The $\mathrm{G}+\mathrm{C}$ content of the DNA is $55 \cdot 5 \mathrm{~mol} \%$ (HPLC).

The type strain, 50-1 $\mathrm{BON}^{\mathrm{T}} \quad\left(=\mathrm{DSM} \quad 15567^{\mathrm{T}}=\mathrm{CIP}\right.$ $\left.107919^{\mathrm{T}}\right)$, was isolated from an Australian oil well in Queensland.

\section{Acknowledgements}

Financial support to M. B. S. from 'Consejo Nacional de Ciencia y Tecnología' (CONACyT) and 'Société Française d'Exportation des Ressources Educatives' (SFERE) is acknowledged. We thank P. Roger for improving the manuscript and S. Pedaccini for technical assistance. Funding from the Australian Research Council to B. K. C. P. and B. O. is gratefully acknowledged.

\section{References}

Altschul, S. F., Madden, T. L., Schäffer, A. A., Zhang, Z., Miller, W. \& Lipman, D. J. (1997). Gapped BLAST and PSI-BLAST, a new generation of protein database search programs. Nucleic Acids Res 25, 3389-3402. 
Balch, W. E., Fox, G. E., Magrum, R. J. \& Wolfe, R. S. (1979). Methanogens: reevaluation of a unique biological group. Microbiol Rev 43, 260-296.

Benson, D. A., Boguski, M. S., Lipman, D. J., Oullette, B. F. F., Rapp, B. A. \& Wheeler, D. L. (1999). GenBank. Nucleic Acids Res 27, 12-17.

Cayol, J.-L., Ollivier, B., Patel, B. K. C., Ravot, G., Magot, M., Ageron, E., Grimont, P. A. D. \& Garcia, J.-L. (1995). Description of Thermoanaerobacter brockii subsp. lactiethylicus subsp. nov., isolated from a deep subsurface French oil well, a proposal to reclassify Thermoanaerobacter finnii as Thermoanaerobacter brockii subsp. finnii comb. nov., and an emended description of Thermoanaerobacter brockii. Int J Syst Bacteriol 45, 783-789.

Cook, G. M., Janssen, P. H. \& Morgan, H. G. (1991). Endospore formation by Thermoanaerobacter brockii HTD4. Syst Appl Microbiol 14, 240-244.

Cord-Ruwisch, R. (1985). A quick method for the determination of dissolved and precipitated sulfides in cultures of sulfate-reducing bacteria. J Microbiol Methods 4, 33-36.

Fardeau, M.-L., Ollivier, B., Patel, B. K. C., Magot, M., Thomas, P., Rimbault, A., Rocchiccioli, F. \& Garcia, J.-L. (1997). Thermotoga hypogea sp. nov., a xylanolytic, thermophilic bacterium from an oilproducing well. Int J Syst Bacteriol 47, 1013-1019.

Fardeau, M.-L., Magot, M., Patel, B. K. C., Thomas, P., Garcia, J.-L. \& Ollivier, B. (2000). Thermoanaerobacter subterraneus sp. nov., a novel thermophile isolated from oilfield water. Int J Syst Evol Microbiol 50, 2141-2149.

Felsenstein, J. (1993). PHYLIP (Phylogenetic Inference Package) version 3.51c. Distributed by the author. Department of Genetics, University of Washington, Seattle, USA.

Grassia, G. S., McLean, K. M., Glénat, P., Bauld, J. \& Sheehy, A. J. (1996). A systematic survey for thermophilic fermentative bacteria and archaea in high temperature petroleum reservoirs. FEMS Microbiol Ecol 21, 47-58.

Hall, T. A. (1999). BioEdit: a user-friendly biological sequence alignment editor and analysis program for Windows 95/98 NT. Nucleic Acids Symp Ser 41, 95-98.

Hungate, R. E. (1969). A roll-tube method for the cultivation of strict anaerobes. Methods Microbiol 3B, 117-132.

Jukes, T. H. \& Cantor, C. R. (1969). Evolution of protein molecules. In Mammalian Protein Metabolism, pp. 211-232. Edited by H. N. Munro. New York: Academic Press.

Koussémon, M., Combet-Blanc, Y., Patel, B. K. C., Cayol, J.-L., Thomas, P., Garcia, J.-L. \& Ollivier, B. (2001). Propionibacterium microaerophilum sp. nov., a microaerophilic bacterium isolated from olive mill wastewater. Int J Syst Evol Microbiol 51, 1373-1382.

Lee, Y.-E., Jain, M. K., Lee, C., Lowe, S. E. \& Zeikus, J. G. (1993). Taxonomic distinction of saccharolytic thermophilic anaerobes: description of Thermoanaerobacterium xylanolyticum gen. nov., sp. nov., and Thermoanaerobacterium saccharolyticum gen. nov., sp. nov.; reclassification of Thermoanaerobium brockii, Clostridium thermosulfurogenes, and Clostridium thermohydrosulfuricum E100-69 as Thermoanaerobacter brockii comb. nov., Thermoanaerobacterium thermosulfurigenes comb. nov., and Thermoanaerobacter thermohydrosulfuricus comb. nov., respectively; and transfer of Clostridium thermohydrosulfuricum 39E to Thermoanaerobacter ethanolicus. Int J Syst Bacteriol 43, 41-51.

Levi, J. D., Regnier, A. P., Vance, A. P. \& Smith, A. D. (1985). MEOR strategy and screening methods for anaerobic oil-mobilizing bacteria. In Microbes and Oil Recovery, vol. I, pp. 336-344. Edited by J. E. Zajic \& E. C. Donaldson. El Paso, TX: Bioresource Publications Press.
L'Haridon, S., Reysenbach, A. L., Glénat, P., Prieur, D. \& Jeanthon, P. (1995). Hot subterranean biosphere in a continental oil reservoir. Nature 377, 223-224.

Liu, S.-Y., Rainey, F. A., Morgan, H. W., Mayer, F. \& Wiegel, J. (1996). Thermoanaerobacterium aotearoense sp. nov., a slightly acidophilic anaerobic thermophile isolated from various hot springs in New Zealand, and emendation of the genus Thermoanaerobacterium. Int J Syst Bacteriol 46, 388-396.

Magot, M., Ollivier, B. \& Patel, B. K. C. (2000). Microbiology of petroleum reservoirs. Antonie van Leeuwenhoek 77, 103-116.

Maidak, B. L., Cole, J. R., Lilburn, T. G. \& 7 other authors (2001). The RDP-II (Ribosomal Database Project). Nucleic Acids Res 29, 173-174.

Mesbah, M., Premachandran, U. \& Whitman, W. B. (1989). Precise measurement of the $\mathrm{G}+\mathrm{C}$ content of deoxyribonucleic acid by highperformance liquid chromatography. Int J Syst Bacteriol 39, 159-167.

Miranda-Tello, E., Fardeau, M.-L., Fernandez, L., Ramirez, F., Cayol, J.-L., Thomas, P., Garcia, J.-L. \& Ollivier, B. (2003). Desulfovibrio capillatus sp. nov., a novel sulfate-reducing bacterium isolated from an oil field separator located in the Gulf of Mexico. Anaerobe 9, 97-103.

Nazina, T. N., Ivanova, A. E., Kanchaveli, L. P. \& Rozanova, E. P. (1988). Desulfotomaculum kuznetsovii sp. nov., a new sporeforming thermophilic methylotrophic sulfate-reducing bacterium. Mikrobiologiya 57, 823-827 (in Russian).

Ng, T. K., Weimer, P. J. \& Zeikus, J. G. (1977). Cellulolytic and physiological properties of Clostridium thermocellum. Arch Microbiol 114, 1-7.

Nilsen, R. K., Torsvik, T. \& Lien, T. (1996). Desulfotomaculum thermocisternum sp. nov., a sulfate reducer isolated from a hot North Sea oil reservoir. Int J Syst Bacteriol 46, 397-402.

Ollivier, B., Fardeau, M.-L., Cayol, J.-L., Magot, M., Patel, B. K. C., Prensier, G. \& Garcia, J.-L. (1998). Methanocalculus halotolerans gen. nov., sp. nov., isolated from an oil-producing well. Int J Syst Bacteriol 48, 821-828.

Ravot, G., Magot, M., Fardeau, M.-L., Patel, B. K. C., Thomas, P., Garcia, J.-L. \& Ollivier, B. (1999). Fusibacter paucivorans gen. nov., sp. nov., an anaerobic, thiosulfate-reducing bacterium from an oilproducing well. Int J Syst Bacteriol 49, 1141-1147.

Saitou, N. \& Nei, M. (1987). The neighbor-joining method: a new method for reconstructing phylogenetic trees. Mol Biol Evol 4, 405-425.

Schink, B. \& Zeikus, J. G. (1983). Clostridium thermosulfurogenes sp. nov., a new thermophile that produces elemental sulphur from thiosulphate. J Gen Microbiol 129, 1149-1158.

Shenman, J. L. \& Vance, I. (1987). Microbially enhanced oil recovery techniques and offshore oil production. In Microbial Problems in the Offshore Oil Industry, pp. 73-91. Edited by E. C. Hill, J. L. Shennan \& R. J. Watkinson. Chichester: Wiley.

Stetter, K. O., Huber, R., Blöchl, E., Kurr, M., Eden, R. D., Fielder, M., Cash, H. \& Vance, I. (1993). Hyperthermophilic archaea are thriving in deep North Sea and Alaskan oil reservoirs. Nature 365, 743-745.

Voordouw, G., Amstrong, S. M., Reimer, M. F., Fouts, B., Telang, A. J., Shen, Y. \& Gevertz, D. (1996). Characterization of $16 \mathrm{~S}$ rRNA genes from oil field microbial communities indicates the presence of a variety of sulfate-reducing, fermentative, and sulfide-oxidizing bacteria. Appl Environ Microbiol 62, 1623-1629.

Wiegel, J. \& Ljungdahl, L. G. (1981). Thermoanaerobacter ethanolicus gen. nov., sp. nov., a new extreme thermophilic, anaerobic bacterium. Arch Microbiol 128, 341-348. 